\title{
New species of Jupiaba Zanata (Characiformes: Characidae) from Serra do Cachimbo, with comments on the endemism of upper rio Curuá, rio Xingu basin, Brazil
}

\author{
José L. O. Birindelli ${ }^{1}$, Angela M. Zanata ${ }^{2}$, Leandro M. Sousa ${ }^{1}$ \\ and André L. Netto-Ferreira ${ }^{1}$
}

\begin{abstract}
A new species of Jupiaba is described from rio Curuá, a tributary of the rio Iriri, rio Xingu basin, Pará State, Brazil. The new species is distinguished from its congeners by the unique combination of teeth cusps of similar size, dentary teeth gradually decreasing in size towards posterior portion, color pattern consisting of dark markings on the base of the majority of lateral body scales, inconspicuous dark elongate humeral blotch and conspicuous dark round blotch on the caudal peduncle, and 21 to 24 branched anal-fin rays. The new species is very similar, and possibly sister taxon to J. meunieri. Comments on the endemism of the fish fauna of the upper rio Curuá are given.

Uma nova espécie de Jupiaba é descrita do rio Curuá, afluente do rio Iriri, bacia do rio Xingu, Estado do Pará, Brasil. A nova espécie difere de seus congêneres pela combinação única de dentes com cúspides aproximadamente de mesmo tamanho e dentes do dentário gradualmente menores posteriormente, pelo colorido que consiste em manchas escuras na base da maioria das escamas laterais do corpo, mancha umeral alongada e inconspícua e mancha caudal redonda e conspícua, e 21 a 24 raios ramificados na nadadeira anal. A nova espécie é similar e possivelmente táxon irmão de $J$. meunieri. Comentários sobre o endemismo da fauna de peixes do alto rio Curuá são fornecidos.
\end{abstract}

Key words: Jupiaba kurua, Jupiaba meunieri, Taxonomy, Neotropical fish.

\section{Introduction}

Jupiaba Zanata is a characid genus that comprises fishes bearing spine-like pelvic bones which protrude anteroventrally through the body wall in some species. In the description of the genus, Zanata (1997) recognized 21 valid species of Jupiaba. More recently, Zanata \& Lima (2005) described $J$. poekotero from the upper rio Tiquié, rio Negro basin, and Pereira \& Lucinda (2007) described J. elassonaktis from the rio Tocantins basin.

Serra do Cachimbo is the highest portion (up to $500 \mathrm{~m}$ a.s.l.; Klammer, 1984) of the Brazilian shield in the Amazon basin. The region comprises the headwaters from both middle Xingu basin (rio Curuá and its tributaries) and Tapajós basin (rio Jamanxim and some tributaries of rio Teles Pires). Although the fish fauna of Serra do Cachimbo is still poorly sampled, at least three collections were undertaken in the area. The first, in 1956 was made by Lauro Travassos during five or so visits to the military base of Força Aérea Brasileira (FAB, "Base do Cachimbo"). The resulting material, deposited at MNRJ, is labeled as from "rio Cachimbo", what may actually refer to the nowadays called rio Braço Norte, a tributary of the right bank of rio Peixoto de Azevedo, in the rio Teles Pires drainage. The second was carried out by Werner Bockerman in 1976 and the resulting material, deposited at MZUSP, is labeled as from "Cachimbo (rio Peixoto de Azevedo)", and may refer to rio Braço Norte or other smaller tributary of rio Peixoto de Azevedo. The third collection, made by Michael Goulding and collaborators in 1984, has taken place in the upper portion of the rio Curuá, from where one species was described so far (Lima \& Birindelli, 2006). Among several other characids, Haroldo Travassos described Deuterodon minor (now

\footnotetext{
${ }^{1}$ Museu de Zoologia da Universidade de São Paulo, Caixa Postal 42494, 04218-970 São Paulo, SP, Brazil. josebirindelli@yahoo.com; leandro.m.sousa@gmail.com; anferreira@gmail.com

${ }^{2}$ Departamento de Zoologia, Instituto de Biologia, Universidade Federal da Bahia, Rua Barão de Geremoabo, s/n, Ondina, 40170-290

Salvador, BA, Brazil. a_zanata@yahoo.com.br
} 
Jupiaba minor; see Travassos, 1960; 1964), based on specimens collected by his father in Serra do Cachimbo. Zanata (1997), examining the material collected by Bockerman in Serra do Cachimbo, recorded three other Jupiaba species as occurring in the area (i.e., at the rio Braço Norte): J. apenima Zanata, J. poranga Zanata, and J. polylepis (Günther).

During a recent expedition to the Serra do Cachimbo, two fairly similar species of Jupiaba sharing an unusual color pattern were collected. One of them, collected in the rio Jamanxim, rio Peixoto de Azevedo and the lower rio Curuá (below the great falls, see discussion), is herein tentatively identified as Jupiaba meunieri (and henceforth referred as $J$. cf. meunieri), a species originally described by Géry et al. (1996) from French Guiana. The second Jupiaba, collected only in the upper rio Curuá (above the great falls) represents an undescribed species, which is presented below. Comments on the fish endemism of the upper rio Curuá at Serra do Cachimbo are also provided.

\section{Material and Methods}

Counts and measurements follow Fink \& Weitzman (1974: 1-2) and Menezes \& Weitzman (1990), except for longitudinal scale rows above lateral line, counted from the middorsal scale row to the lateral line, not including the scale of the middorsal row immediately anterior to the dorsal-fin origin or the small scale on the dorsal-fin base; and scales rows below lateral line, counted from the lateral line to the pelvic-fin origin, half scale only counted when the scale immediately anterior to the pelvic-fin origin has at least half height above the pelvicfin insertion. Scales along the middorsal line between the tip of the supraoccipital process and the origin of the dorsal fin were only counted when arranged in a regular row. Meristic data are given in the descriptions, the frequency of each count is provided in parentheses after the respective count, and an asterisk indicates counts of the holotype. Vertebrae, supraneurals, procurrent caudal-fin rays, branchiostegal rays, gill-rakers, and dentary teeth counts were taken only from cleared and stained paratypes (cs), prepared according to the method of Taylor \& Van Dyke (1985). Vertebrae of the Weberian apparatus were counted as four elements, included in the vertebral counts, and the fused PU1+U1 of the caudal region as a single element. Patterns of circuli and radii were defined on scales sampled from the region between the lateral line and the insertion of the dorsal fin. In the material listed, specimens are all alcohol preserved, except when indicated by cs. Institutional abbreviations follows Ferraris (2007).

\section{Jupiaba kurua, new species}

Figs. 1-3

Holotype. MZUSP 98000 (77.7 mm SL), Brazil, Pará, Altamira, rio Curuá, rio Iriri drainage, in cofferdam of $\mathrm{PCH}$ (=small hydroelectric dam) Buriti, 846'09”S, 5457'02'W, 21 Oct 2007, J. L. O. Birindelli, L. M. Sousa, A. L. Netto-Ferreira, M. H. Sabaj Pérez \& N. Lujan.

Paratypes. All from Brazil, Pará, Altamira, Iriri drainage: ANSP 187419 (5, 63.4-74.8 mm SL), AUM 47568 (2, 66.4-67.1 mm SL), INPA 28857 (2,0 65.1-66.8 mm SL), MNRJ 31913 (2, 64.6-66.0 mm SL), MZUSP 96857 (70, 51.9-86.0 mm SL, 5 cs, 56.4-77.6 mm SL), UFBA 3943 (8, 56.5-77.9 mm SL), collected with holotype. MZUSP 31864 (1, $79.8 \mathrm{~mm}$ SL), MZUSP 77566 (1, $30.5 \mathrm{~mm} \mathrm{SL})$, rio Curuá, Serra do Cachimbo, 15 Aug 1984, M. Goulding. MZUSP 96939 (1, $58.1 \mathrm{~mm} \mathrm{SL})$, rio Curuá, above the falls, 844'09”S, 54 $57^{\prime} 46^{\prime \prime} \mathrm{W}, 20$ Oct 2007, J. L. O. Birindelli et al., MZUSP 97105 $(60,45.9-82.3 \mathrm{~mm} \mathrm{SL}, 1 \mathrm{cs}, 69.1 \mathrm{~mm} \mathrm{SL})$, rio Curuá, upstream of dam, 846'28'S, 5457'12'W, 21 Oct 2007, J. L. O. Birindelli et al., MZUSP 101299 (16,74.8-86.6 mm SL), rio Curuá, below dam, 8`44'30”'S, 5457'35'W, 23 Jan 2009, A. L. Netto-Ferreira et al., MZUSP 101306 (1, $74.9 \mathrm{~mm} \mathrm{SL})$, rio Curuá, 900’40"S, 545'ㄱ'”, 22 Jan 2009, A. L. Netto-Ferreira et al.

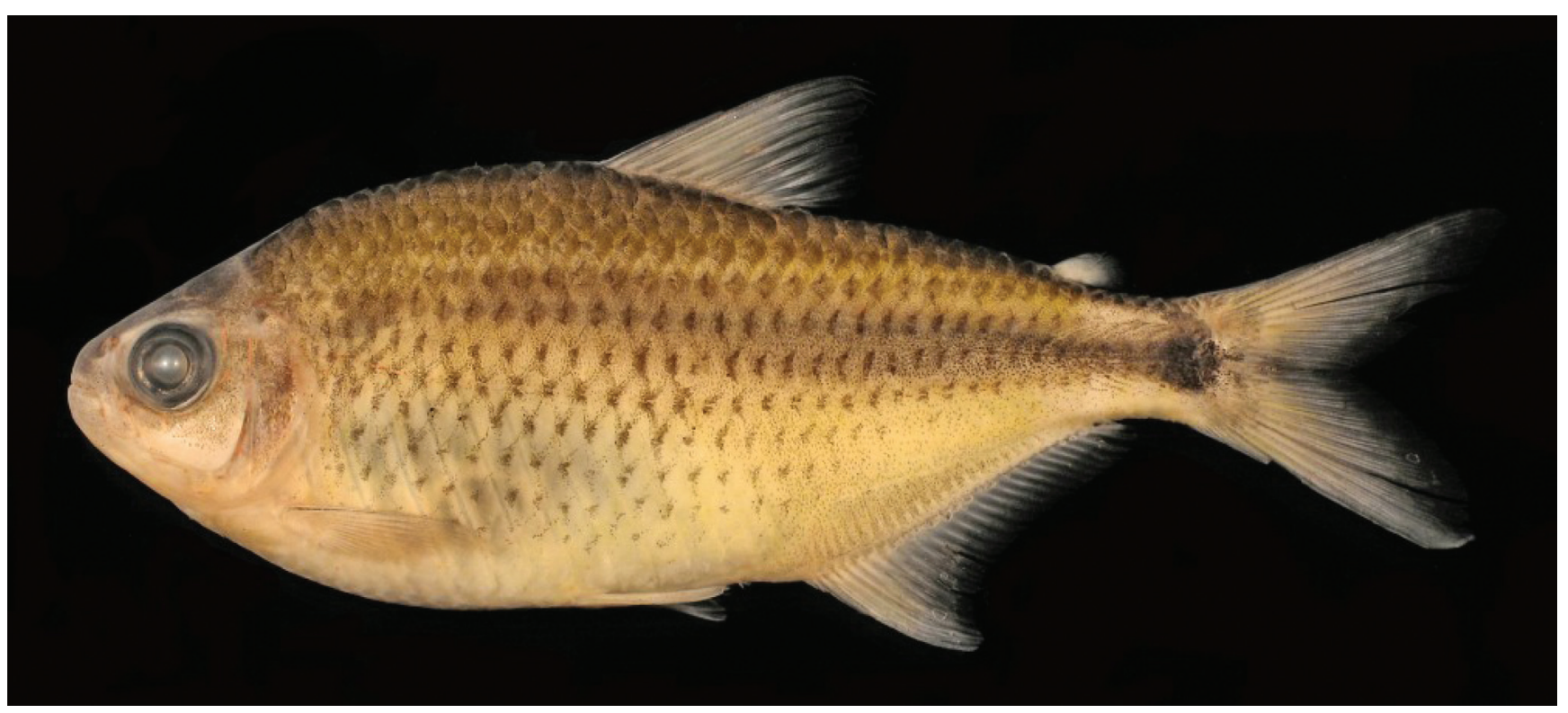

Fig. 1. Jupiaba kurua, holotype, MZUSP 98000, 77.7 mm SL, upper rio Curuá, Xingu basin. 


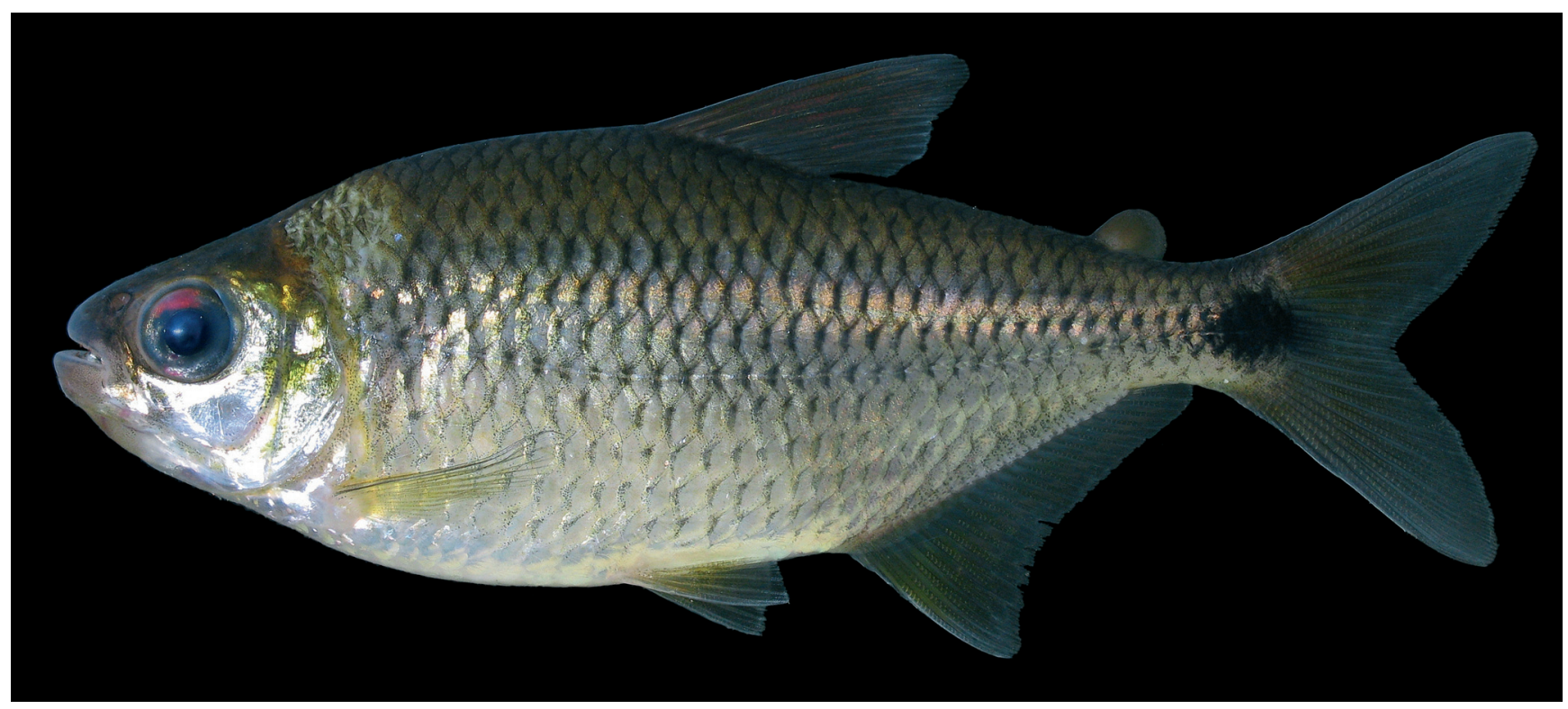

Fig. 2. Jupiaba kurua, live paratype, MZUSP 101299, approximately 80.0 mm SL, upper rio Curuá, Xingu basin.

Diagnosis. Jupiaba kurua is distinguished from its congeners, except $J$. acanthogaster (Eigenmann), J. atypindi Zanata, J. keithi (Géry, Planquette \& LeBail), J. maroniensis (Géry, Planquette \& LeBail), J. meunieri, J. minor and J. pinnata (Eigenmann), by the presence of teeth cusps of similar size and dentary teeth gradually decreasing in size posteriorly. The new species differs from the aforementioned congeners, except $J$. meunieri, by the color pattern that consists of dark dots on the base of the majority of lateral body scales, inconspicuous dark elongated humeral blotch and wellmarked dark round blotch on the caudal peduncle. Jupiaba kurua is further distinguished from $J$. meunieri (as well as similar species such as J. maroniensis) by having 5 to 6 scale series between lateral line and pelvic-fin origin ( $v s .6 .5$ to 7.5 ), 21 to 24 branched anal-fin rays (vs. 25 to 31 ), body depth at dorsal-fin origin 33.3 to $40.2 \%$, mean $36.3 \%$ of SL ( $v s .42 .7$ to $47.9 \%$, mean $45.5 \%$ of SL, based on examined specimens).

Description. Morphometric data of the holotype and paratypes given in Table 1. Body compressed, moderately elongate. Greatest body depth slightly anterior to dorsal-fin origin. Dorsal profile convex from upper lip to vertical through anterior nostrils, straight from latter point to tip of supraoccipital spine, convex from that point to terminus of dorsal-fin base, straight from latter point to adipose fin, and slightly concave between adipose fin to origin of dorsalmost procurrent caudal-fin ray. Ventral profile convex from lower lip to anal-fin origin (in some specimens nearly straight between anterior tips of pelvic-spine and anal-fin origin), straight along anal-fin base, and slightly concave from terminus of anal-fin base to caudal peduncle.

Jaws equal in length, mouth terminal. Posterior terminus of maxilla barely reaching to slightly trespassing vertical through anterior margin of orbit. Teeth somewhat compressed, cusps aligned along distal tooth margin. Premaxillary teeth in two rows (Fig. 3), four (5) or five (1) pentacuspid teeth on outer row, five (6) teeth bearing seven to nine cusps on inner row; symphyseal tooth of inner series comparatively small, asymmetrical, with lower number of cusps on anteromedial side. Maxilla with two (6) teeth bearing five or seven cusps; anteriormost tooth usually the largest. Nine (4) or ten (2) teeth on dentary; medial teeth with seven or nine cusps, posterior ones tricuspid or conic; symphyseal tooth usually symmetrical, with central cusp slightly larger than remaining cusps. Majority of remaining teeth asymmetrical, with lower number of cusps on medial side of tooth. Dentary teeth gradually decreasing in size and in number of cusps posteriorly.

Scales cycloid, circuli restricted to covered area of scales, with few slightly divergent radii extending to posterior margin of scales. Lateral line slightly curved ventrally, 36 (19), 37* (22), or 38 (1) perforated scales continuous from supracleithrum to base of caudal fin. Longitudinal scale rows between dorsal-fin origin and lateral line six (20) or seven* (22). Longitudinal scale rows between lateral line and pelvicfin origin five (19), 5.5* (20) or six (3). Scales along middorsal line between tip of supraoccipital process and origin of dorsal fin nine (11), ten* (18), 11 (10), or 12 (3). Horizontal scale rows around caudal peduncle 14 (42). Single row of eight to ten scales covering base of anterior most anal-fin rays.

Dorsal-fin rays ii, 9 (42), distal margin of dorsal fin straight to slightly concave. Dorsal-fin origin slightly anterior to middle of standard length, first dorsal-fin pterygiophore inserting posterior to neural spine of nineth (5) vertebra and posterior insertion of dorsal fin slightly anterior to vertical through anal-fin origin. Adipose fin present. Anal-fin rays iv or v, 21 (13), 22* (20), 23 (8), or 24 (1), distal margin of anal fin concave; first anal-fin pterygiophore inserting posterior to haemal spine of $18^{\text {th }}$ (1) $19^{\text {th }}$ (4) vertebra. Pectoral-fin rays $i, 11$ (2), 12 (14), $13 *(23)$ or $14(2)$, tip of pectoral fin reaching shy to vertical 
Table 1. Morphometric data for Jupiaba kurua.

\begin{tabular}{|c|c|c|c|c|c|}
\hline & $\mathrm{n}$ & mean & range & $\mathrm{SD}$ & Holotype \\
\hline Standard Length $(\mathrm{mm})$ & \multicolumn{5}{|c|}{ Percents of SL } \\
\hline Depth at dorsal-fin origin & 42 & 36.33 & $33.33-40.17$ & 1.40 & 37.56 \\
\hline Snout to dorsal-fin origin & 42 & 48.89 & $47.20-51.36$ & 0.93 & 49.77 \\
\hline Snout to pectoral-fin origin & 42 & 22.32 & $20.75-24.20$ & 0.88 & 20.93 \\
\hline Snout to pelvic-fin origin & 42 & 46.56 & $44.95-49.55$ & 1.08 & 46.98 \\
\hline Snout to anal-fin origin & 42 & 64.38 & $61.99-68.60$ & 1.41 & 65.47 \\
\hline Caudal peduncle depth & 42 & 9.89 & $9.17-10.70$ & 0.31 & 9.77 \\
\hline Caudal peduncle length & 42 & 11.33 & $9.77-13.60$ & 0.85 & 12.09 \\
\hline Pectoral-fin length & 42 & 20.75 & $18.73-22.03$ & 0.88 & 19.19 \\
\hline Pelvic-fin length & 42 & 14.73 & $12.78-16.27$ & 0.87 & 13.72 \\
\hline Pelvic-bone length & 42 & 9.20 & $7.02-11.02$ & 0.95 & 9.53 \\
\hline Dorsal-fin base length & 42 & 15.24 & $13.55-16.78$ & 0.74 & 15.12 \\
\hline Dorsal-fin length & 42 & 26.32 & $24.15-30.42$ & 1.26 & 25.12 \\
\hline Anal-fin base length & 42 & 27.73 & $25.44-31.42$ & 1.14 & 27.44 \\
\hline Anal-fin lobe length & 42 & 16.64 & $13.84-18.26$ & 1.01 & 13.84 \\
\hline Eye to dorsal-fin origin & 42 & 37.03 & $34.45-39.37$ & 1.13 & 38.14 \\
\hline Dorsal-fin origin to caudal-fin 1 & ase 42 & 54.28 & $51.02-56.57$ & 1.33 & 54.30 \\
\hline Bony head length & 42 & 22.85 & $21.09-24.59$ & 0.72 & 22.33 \\
\hline \multicolumn{6}{|c|}{ Percents of head length } \\
\hline Horizontal eye diameter & 42 & 35.02 & $30.59-38.41$ & 1.79 & 33.85 \\
\hline Snout length & 42 & 28.40 & $24.20-32.94$ & 1.65 & 28.13 \\
\hline Least interorbital distance & 42 & 35.79 & $32.47-39.16$ & 1.44 & 37.50 \\
\hline Upper jaw length & 42 & 40.67 & $37.76-45.83$ & 1.54 & 39.58 \\
\hline
\end{tabular}

through pelvic-fin origin. Pelvic-fin rays i, 7 (42); pelvic bone elongate, modified into spine, with anterior portion diverging (in relation to its counterpart) but usually not protruding through body wall. Principal caudal-fin rays $10+9$ (42); caudal fin forked, lobes slightly rounded, of similar size. Ten (2) dorsal procurrent caudal-fin rays, and nine (2) ventral procurrent caudal-fin rays. Gill-rakers on first gill arch six (2) or seven (3) on epibranchial, one (5) on cartilage between ceratobranchial and epibranchial, nine (5) on ceratobranchial, and two (5) on hypobranchial. Vertebrae 35 (4) or 36 (1). Supraneurals five (5). Branchiostegal rays four (5).

Color in alcohol. Ground color tan, darker dorsally. Small dark chromatophores densely concentrated on dorsal surface of head from upper lip to supraoccipital spine. Dense pigmentation continuing posteriorly throughout middorsal line of body. Maxilla, infraorbitals, and opercle with scattered dark chromatophores; in some specimens chromatophores more concentrated on region close to orbit or on upper half of opercle. Ventral portion of head less pigmented, with scattered small dark chromatophores from lip to vertical through anterior margin of orbit.

Scales of dorsal portion of body darkened (especially the three to five dorsalmost horizontal series), with small dark chromatophores distributed over entire scales or leaving only small anterocentral portion somewhat pale. Scales from two to three series above and below lateral line with dark chromatophores concentrated on basal portion. Resulting color pattern consisting of five to six lines of spots along lateral of body. Abdominal region yellow, without dark chromatophores.

Humeral region with a poorly-defined blotch, followed by an inconspicuous midlateral stripe relatively wide, formed by small subjacent dark chromatophores; stripe continuous with caudal blotch. Caudal peduncle blotch rounded, not reaching

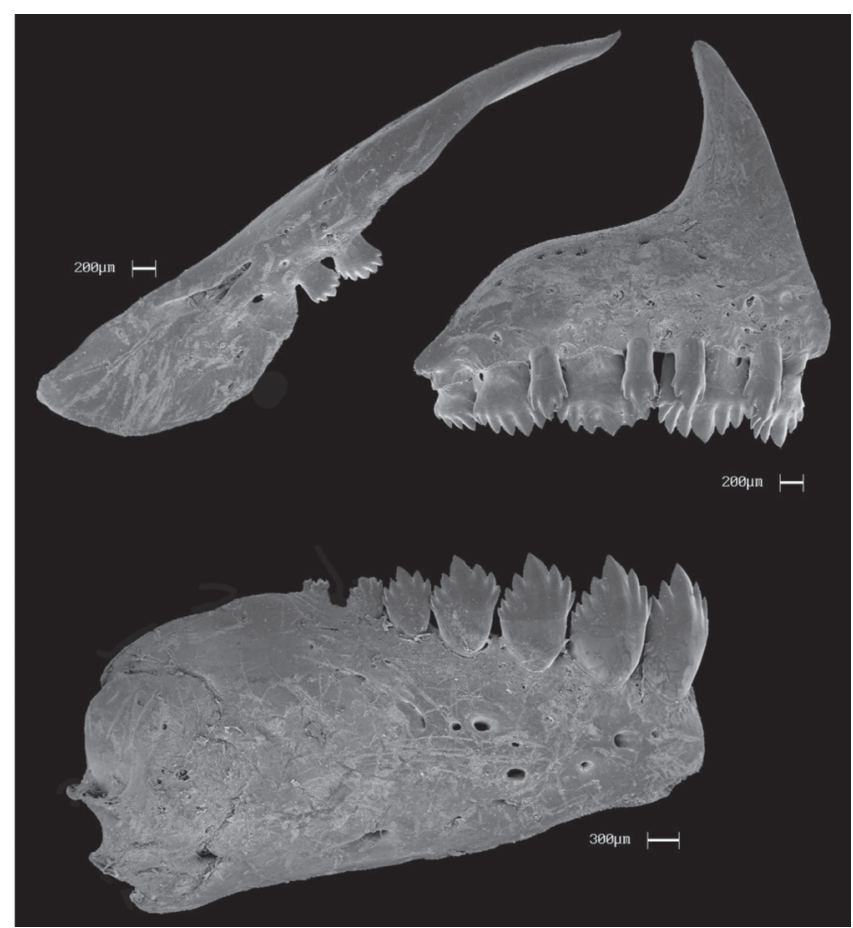

Fig. 3. Jupiaba kurua, paratype, MZUSP 96857, $77.6 \mathrm{~mm}$ SL. Scanning eletronic microscopy of left side of upper and lower jaws (figure re-oriented).

dorsal and ventral borders of caudal peduncle; some specimens with caudal peduncle blotch, extending as a faded stripe onto median caudal-fin rays. Dark chromatophores concentrated along lateral margins of caudal-fin rays.

Dorsal fin with scattered dark pigmentation. Anal fin darkened in similar pattern as dorsal fin, but with chromatophores more concentrated along its distal border, forming inconspicuous dark band. Pectoral and pelvic fins with dark chromatophores distributed along lateral margins of rays. Adipose fin with scattered dark chromatophores.

Color in life. Body and head tending to pale below lateral midline, tan and darker dorsally. Dorsal and adipose fins somewhat orange, pectoral, pelvic, anal, and caudal fins yellow. Anal fin with dark distal band. Eyes black, except for red anterodorsal portion.

Sexual dimorphism. Bony hooks present on pelvic and analfin rays of 15 male specimens. Pelvic-fin hooks distributed on median to distalmost portions of last unbranched and first to seventh branched rays (hooks not fully developed in some specimens).

Geographic distribution. Jupiaba kurua is known from the upper rio Curuá, above the two great falls in Serra do Cachimbo (Fig. 4). Rio Curuá is a tributary of rio Iriri, the latter a large tributary of lower rio Xingu. Collections made below the waterfalls indicate that the new species may be restricted to the isolated river portion above the falls (see discussion for more details on the endemism of upper rio Curuá). 


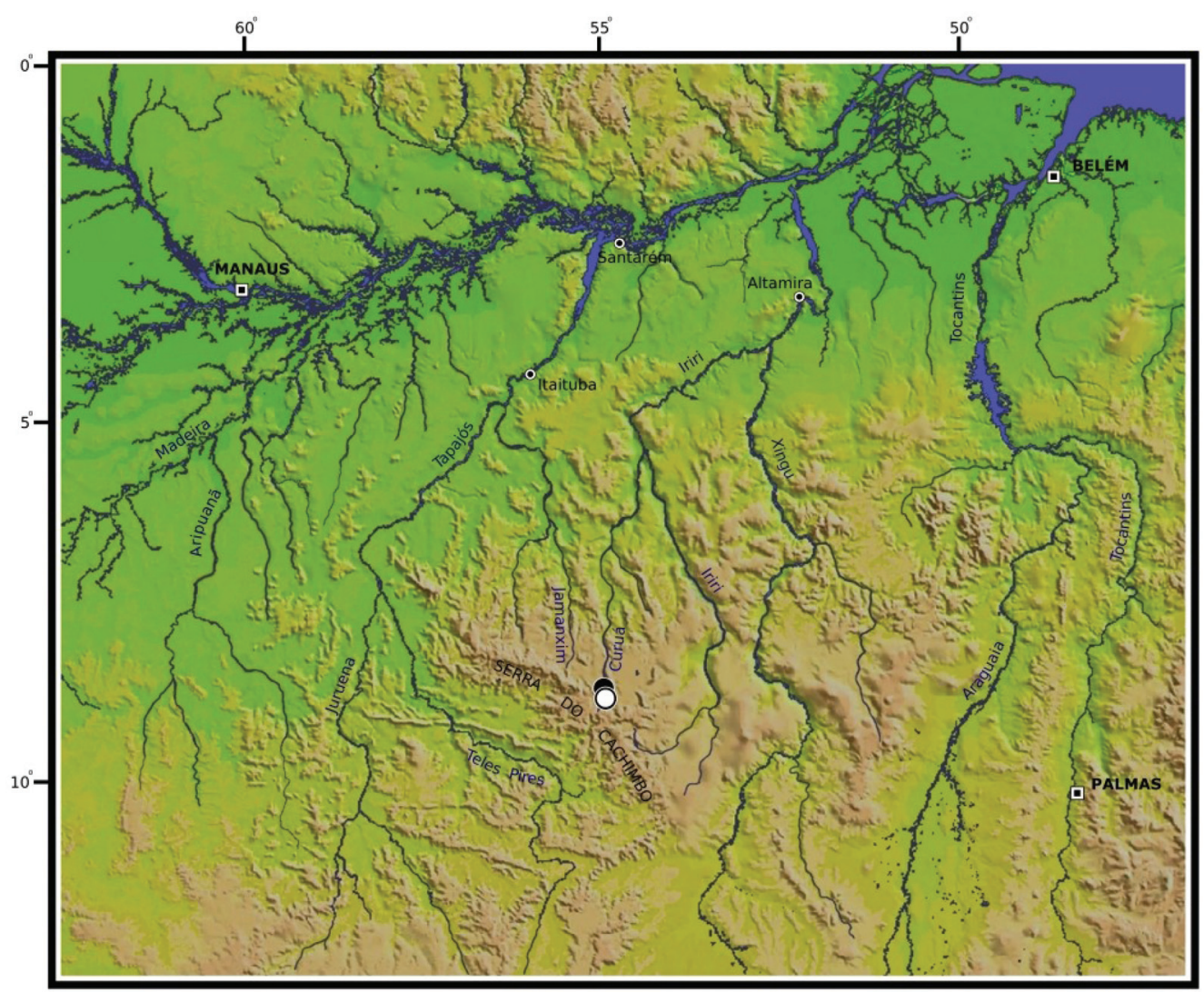

Fig. 4. Distribution of Jupiaba kurua in rio Curuá, Xingu basin, central Brazil (type locality represented by open circle).

Ecological notes. The rio Curuá is a clear water river. Analysis of the stomach contents of six cleared and stained paratypes revealed the presence of termites, ants, small wasps, mayfly nymphs, dipteran larvae, chironomid larvae, pupae and adults, caddis fly larvae, characiform scales, fin rays, Podostemaceae fragments, filamentous algae, sediment, unidentified insect fragments and unidentified vegetal fragments. Even though podostemacean fragments and filamentous algae were the main food items on the specimens examined, presence of additional allochthonous insects and other autochthonous items suggests that Jupiaba kurua is an omnivorous species with a considerable plasticity on its diet. The broad range of food items on this species' diet also suggests that it explores the resources available along the entire water column.

Etymology. From the tupi language kurua, in allusion to the type locality, rio Curuá. A noun in apposition.

\section{Discussion}

The new species belongs to the genus Jupiaba, a monophyletic unit defined by a series of synapomorphies (Zanata, 1997; Zanata \& Lima, 2005), which include the presence of elongate pelvic bone, developed as a spine and with its anteriormost portion free from the musculature. There is no comprehensive hypothesis of the inter-relationships between the species of Jupiaba. Nevertheless, it is noteworthy that $J$. kurua shares with $J$. acanthogaster, $J$. atypindi, J. keithi, J. maroniensis, J. meunieri, J. minor, J. pinnata, and $J$. poekotero the presence of premaxillary and maxillary teeth somewhat compressed, with cusps of similar size, and dentary teeth decreasing gradually in size posteriorly ( $v s$. more robust teeth bearing one largest median cusp and small lateral ones, and larger dentary teeth anteriorly followed by distinctly smaller teeth, in the remaining congeners). The presence of dark dots on the base of the majority of lateral body scales and the coloration of the eye in live specimens (i.e., eye black except for a red anterodorsal portion) of $J$. kurua are features shared only with J. meunieri (see Fig. 5), and seems to indicate a close phylogenetic relationship between both species.

As defined by Zanata \& Lima (2005), the pelvic-fin spine of the species of Jupiaba can be either well-developed, with a large portion exserted from the body wall, with only its anterior tip exserted or yet completely covered by a thin layer of skin, usually visible by transparency. In $J$. kurua, as in $J$. meunieri, the majority of the specimens have the pelvic spine completely covered by skin, however four specimens have the anterior tip of the spine exserted from the body wall. Although the significance of having spine-like pelvic bones remains poorly understood, it probably has some important role in the ecology of Jupiaba species.

The stretch of rio Curuá near Vila de Cachoeira da Serra (approximately at $8^{\circ} 44^{\prime} \mathrm{S}, 54^{\circ} 58^{\prime} \mathrm{W}$ ) has two large waterfalls 


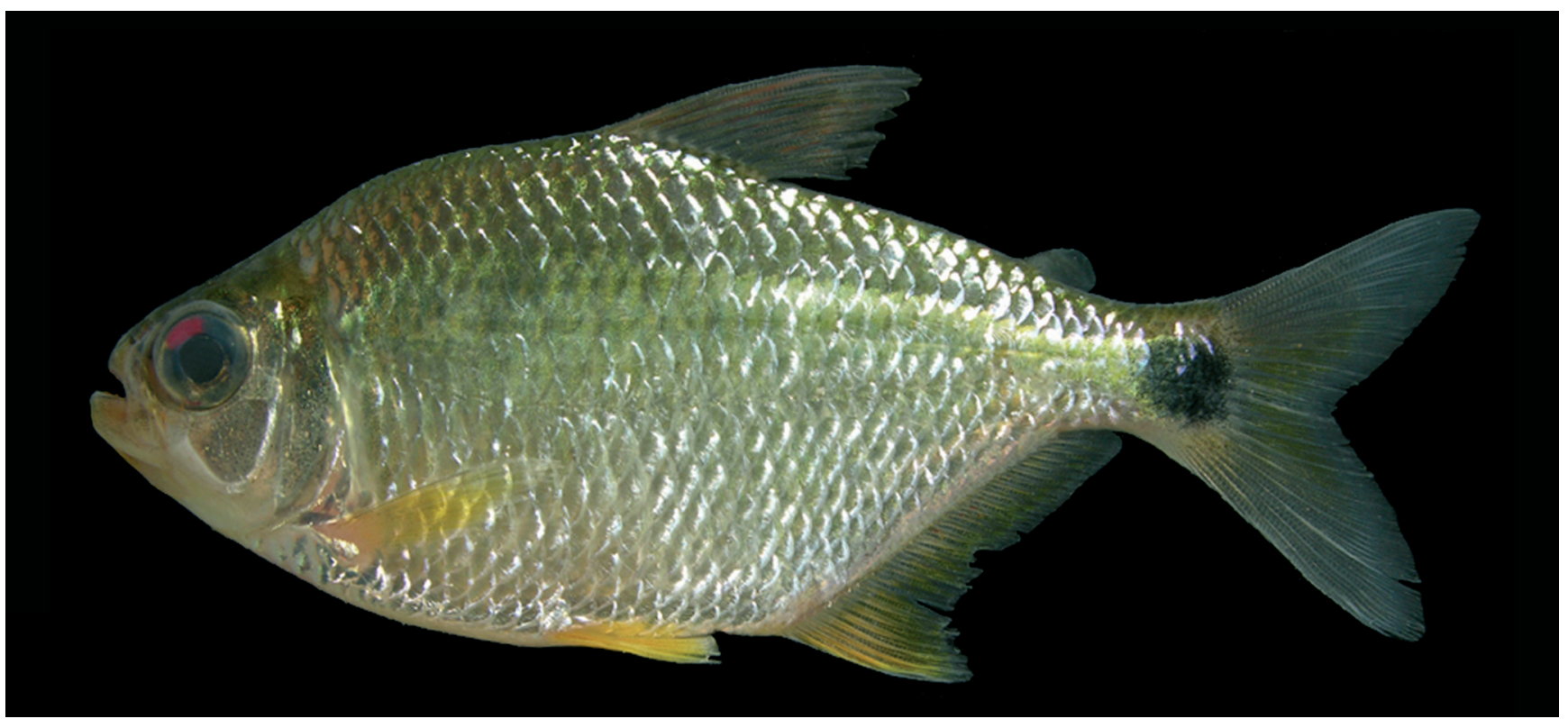

Fig. 5. Jupiaba cf. meunieri, live specimen, MZUSP 96817, 78.0 mm SL, Cachoeira da Neblina, rio Peixoto de Azevedo, tributary of rio Teles Pires, Tapajós basin. Photo by Mark Sabaj Pérez.

of approximately 60 (Fig. 6a) and 40 (Fig. 6b) meters high, immediately above them, above three of the smaller falls, and separated only by a 50 meter river stretch. Above them, there above all five smaller falls in the main river and in its tributaries. are at least five smaller (up to 5 meters high) waterfalls (Fig. The fish fauna above and below the large falls seems to be $6 \mathrm{c})$. Recently, we collected fishes below the great falls, quite distinct. Above them, in addition to Jupiaba kurua, we
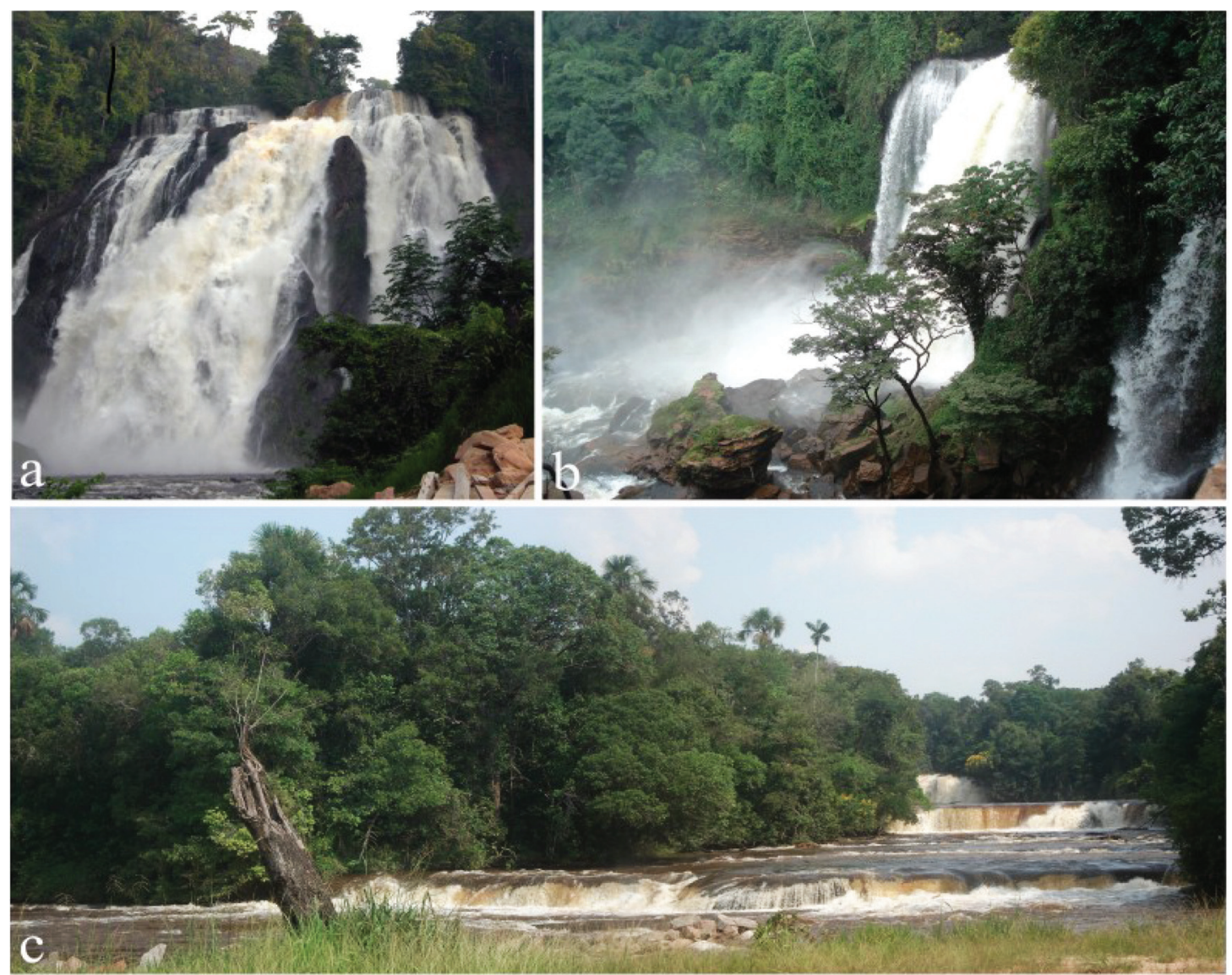

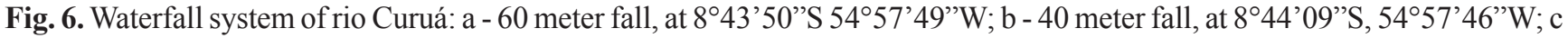
- three smaller falls of approximately 1 to 5 meters, at 8 $46^{\prime} 09^{\prime} \mathrm{S} 54^{\circ} 57^{\prime} 02^{\prime \prime} \mathrm{W}$. 
sampled 35 species of fish, from which at least 13 (e.g., Moenkhausia petymbuaba Lima \& Birindelli, 2006; Leporinus guttatus Birindelli \& Britski, 2009), either seems to be restricted to the portion of rio Curuá above the falls (upper rio Curuá), or occur between the upper rio Curuá and tributaries of rio Braço Norte (e.g. Hyphessobrycon cf. cachimbensis). Below the falls we collected 97 species, several of them also recorded for the lower Xingu basin. This indicates that the upper rio Curuá has a highly endemic fish fauna. Similarly, the rio Treze de Maio, a tributary of the left margin of rio Curuá below the falls, also has, in its uppermost portion, three smaller waterfalls followed (downstream) by a large fall of about 80 meters high. Although the collection effort in the latter area was considerably lower, we collected 11 species in the upper rio Treze de Maio, from which at least five species seems to be endemic, and 30 species below the falls, where the fish fauna is very similar to the one from the portion of rio Curuá below the falls. This also indicates an isolation of the fish fauna in the upper rio Treze de Maio due to the presence of a large waterfall.

In conclusion, our results corroborate the prediction by Goulding et al. (2003: 139) that in the Serra do Cachimbo area "fish populations have probably been isolated in the areas above the waterfalls and there are probably many endemic species". Unfortunately, the upper rio Curuá is currently under intense anthropogenic pressure in the form of hydroelectric dam building, deforestation, and cattle ranching. In view of the apparent high fish endemism in the area, we suggest that special efforts should be directed for the conservation of the Serra do Cachimbo environment and wild life.

Comparative material examined. Jupiaba maroniensis: MZUSP 99681 (9, 31.5-51.8 mm SL), rio Marowjine (=Maroni). Jupiaba cf. meunieri (Brazil): MZUSP 54556 (1, $49.5 \mathrm{~mm} \mathrm{SL})$, rio Jari, Cachoeira Santo Antônio, Monte Dourado, Pará. MZUSP 87167 (5, 50.3-75.5 mm SL), ribeirão Macuco, 74 km from Sinop, Tapajós basin, São José do Rio Claro, Mato Grosso. MZUSP 95760 (2, 59.7-78.5 mm SL), rio Matrinchã, tributary of rio Teles Pires, Tapajós basin, Itaúba, Mato Grosso. MZUSP 96015 (1, 80.0 mm SL), tributary of rio Teles Pires, Tapajós basin, Itaúba, Mato Grosso. MZUSP 96817 (39, 49.5-103.8 mm SL), Cachoeira da Neblina, rio Peixoto de Azevedo, tributary of rio Teles Pires, Tapajós basin, Peixoto de Azevedo, Mato Grosso. MZUSP 96983 (2, 53.6-86.6 $\mathrm{mm}$ SL), rio Curuá, below the falls, Xingu basin, Altamira, Pará. MZUSP 97135 (2, 61,7-68,0 mm SL), rio Treze de Maio, tributary of rio Curuá, Xingu basin, Altamira, Pará. MZUSP 97146 (11, 48.6-60.2 mm SL), rio Curuá, at Vila de Castelo dos Sonhos, Altamira, Pará. MZUSP 97284 (6, 45.5-51.8 mm SL), rio Jamanxim, Novo Progresso, Pará. MZUSP 97327 (9, 43.2-51.4 mm SL), rio Jamanxim, Novo Progresso, Pará. MZUSP 97556 (1, 72.0 mm SL), tributary of rio Jamanxim, Tapajós basin, Novo Progresso, Pará.

\section{Acknowledgments}

We are grateful to Flávio C. T. Lima, Cristiano R. Moreira and two anonymous reviewers for comments and suggestions on the manuscript. For loan of specimens we thank Mark
Sabaj Pérez (ANSP), Nathan Lujan (AUM), Paulo A. Buckup (MNRJ), and Marcelo Rocha and Lúcia Rapp Py-Daniel (INPA). We are grateful to Mark Sabaj Pérez, Nathan Lujan and Pedro Hollanda Carvalho for their help and assistance during the field expeditions. Specimens used in this study were collected during an expedition to Serra do Cachimbo, a joint collaboration of MZUSP, ANSP, and AUM, funded by All Catfish Species Inventory (NSF DEB-0315963). Authors were financially supported by FAPESP (grants 06/53737-7JLOB, 06/04162-1-LMS and 06/04161-5-ALNF).

\section{Literature Cited}

Birindelli, J. L. O. \& H. A. Britski. 2009. New species of the genus Leporinus Agassiz (Characiformes: Anostomidae) from the rio Curuá, rio Xingu basin, Serra do Cachimbo, Brazil, with comments on Leporinus reticulatus. Neotropical Ichthyology, 7(1): $1-10$.

Ferraris, Jr., C. J. 2007. Checklist of catfishes, recent and fossil (Osteichthyes: Siluriformes), and catalogue of siluriform primary types. Zootaxa, 1418: 1-628.

Fink, W. L. \& S. H. Weitzman. 1974. The so-called cheirodontin fishes of Central America with description of two new species (Pisces, Characidae). Smithsonian Contributions to Zoology, 172: 1-46.

Géry, J., P. Planquette \& P. -Y. Le Bail. 1996. Nouvelles especes guyanaises d'Astyanax S.L. (Teleostei, Characiformes, Characidae) a epines pelviennes, avec une introduction concernant le groupe. Cybium, 20(1): 3-36.

Goulding, M., R. Barthem \& E. Ferreira. 2003. The Smithsonian atlas of the Amazon. Smithsonian Books, Washington, 253p.

Klammer, G. 1984. The relief of the extra-Andean Amazon basin. Pp. 47-84. In: H. Sioli (ed.), The Amazon: limnology and landscape ecology of a mighty tropical river and its basin. Junk, Dordrecht, 749p.

Lima, F. C. T. \& J. L. O. Birindelli. 2006. Moenkhausia petymbuaba, a new species of characid from the Serra do Cachimbo, rio Xingu basin, Brazil (Characiformes: Characidae). Ichthyological Explorations of Freshwaters, 17(1): 53-58.

Menezes, N. A. \& S. H. Weitzman. 1990. Two new species of Mimagoniates (Teleostei: Characidae: Glandulocaudinae), their phylogeny and biogeography and a key to the glandulocaudin fishes of Brazil and Paraguay. Proceedings of the Biological Society of Washington, 103: 380-426.

Planquette, P., P. Keith \& P. -Y. Le Bail. 1996. Atlas dês poissons d'eau douce de Guyane, tome 1. Collection du Patrimoine Naturel, vol. 22. IEGB - M.N.H.N., INRA, CSP, Min. Env., Paris, 429p.

Pereira, T. N. A. \& P. F. Lucinda. 2007. A new species of Jupiaba Zanata, 1997 (Ostariophysi, Characiformes, Characidae) from the rio Tocantins drainage, Brazil. Zootaxa, 1614: 53-60.

Taylor, W. R. \& G. C. Van Dyke. 1985. Revised procedures for staining and clearing small fishes and other vertebrates for bone and cartilage study. Cybium, 9: 107-109.

Travassos, H. 1960. Notas Ictiológicas. X. "Astyanax saltor" sp. n., do Estado do Pará, Brasil (Actinopterygii, Cypriniformes, Characoidei). Revista Brasileira de Biologia, 20(1): 17-20.

Travassos, H. 1964. Sôbre alguns peixes do Estado do Pará, Brasil. Anais da Academia Brasileira de Ciências, 36(4): 538-548. 
Zanata, A. M. 1997. Jupiaba, um novo gênero de Tetragonopterinae com osso pélvico em forma de espinho (Characidae, Characiformes). Iheringia, série Zoologia, 83: 99-136.

Zanata, A. M. \& F. C. T. Lima. 2005. New species of Jupiaba (Characiformes: Characidae) from Rio Tiquié, Upper Rio Negro Basin, Brazil. Copeia, 2005(2): 272-278.

Accepted February 2009

Published March 31, 2009 